\title{
Peran Tradisi “Pencak” sebagai implementasi budaya lokal dalam bingkai kehidupan masyarakat Pujon
}

\author{
Khoirul Umam, Irawan* \\ Universitas Negeri Malang, Jl. Semarang No. 5 Malang, Jawa Timur, Indonesia \\ *Penulis korespondensi, Surel: irawan.fis@um.ac.id
}

Paper received: 01-04-2021; revised: 16-04-2021; accepted: 30-04-2021

\begin{abstract}
Abstrak
Budaya lokal merupakan konsep dari tradisi yang bersumber dari kegiatan ataupun ritual yang biasa dilakukan oleh masyarakat dalam satu wilayah tertentu, atau budaya lokal juga dapat dikatakan sebagai suatu identitas yang melekat pada suatu daerah. Daerah Pujon merupakan salah satu daerah dengan beberapa tradisi atau budaya lokal yang terdapat di dalamnya salah satunya yakni tradisi pencak, yang merupakan tradisi atau budaya lokal dari masyarakat Pujon yang mengadopsi tradisi pencak silat namun dengan versi tradisional dengan perlengkapan-perlengkapan dan aspek-aspek tertentu di dalamnya. Urgensi dan tujuan dari kajian ini adalah untuk mengetahui bagaimana peranan dari tradisi pencak tradisional ini dalam kehidupan masyarakat Pujon, selain itu kajian atau artikel ini juga ditujukan untuk mengetahui aspek-aspek apa saja yang terdapat dalam proses pencak itu sendiri. Dalam penyusunan artikel ini penulis menerapkan metode kualitatif, yakni dengan mengadakan riset sederhana mengenai topik bahasan yang akan dibahas dalam artikel ini, melalui observasi, wawancara dan studi pustaka untuk mencari sumber literatur yang dapat menunjang proses pengembangan topik dari artikel ini, baik literatur secara online maupun offline. Dari hasil analisis yang sudah dilakukan mengenai topik bahasan ini, dapat diketahui bahwa dengan adanya tradisi pencak ini membuat masyarakat menjadi lebih mencintai budayanya melalui pelestarian budaya yang selalu dijaga, selain itu dalam tradisi pencak ini juga terdapat beberapa aspek yang ada dalam masyarakat, baik dari aspek sosial, ekonomi, kepercayaan dan yang lainnya, dimana aspekaspek ini saling berkesinambungan dalam tradisi pencak tersebut.
\end{abstract}

Kata kunci: Tradisi Pencak; budaya lokal; masyarakat Pujon

\section{Pendahuluan}

Budaya merupakan bentuk bahasa yang berasal dari bahasa sansekerta yakni Buddhayah yang berkonotasi dengan kalimat Budhi dan Daya dengan pemaknaan berupa akal dan kekuatan. Budaya juga dapat didefinisikan sebagai sebuah bentuk konstruksi pemaknaan baik melalui suatu simbol ataupun yang lainnya, dengan tujuan sebagai suatu bentuk representasi dari hal-hal yang dianggap memiliki makna tertentu dalam masyarakat (Glifford G, 1986). Sedangkan budaya lokal merupakan bentuk representasi kebiasaan yang sering dilakukan oleh masyarakat dalam satu ruang lingkup wilayah yang berhubungan dengan beberapa aspek dalam masyarakat seperti aspek kepercayaan, sosial, ekonomi, dan yang lainnya. Budaya lokal memiliki sifat pelestarian yang dilakukan secara turun temurun dari nenek moyang, bentuk-bentuk dari budaya lokal dapat berupa tradisi, adat istiadat, kesenian, pola pemikiran dan yang lainnya. Salah satu contoh dari budaya lokal adalah tradisi pencak yang terdapat di Kecamatan Pujon, Kabupaten Malang.

Kecamatan Pujon merupakan salah satu kecamatan yang terdapat di bagian barat Kabupaten Malang dengan luas Kecamatan Pujon secara keseluruhan sekitar 34,18 km atau setara dengan 4,39\% dari keseluruhan luas Kabupaten Malang, sedangkan dari segi astronomis Kecamatan Pujon terletak antara 112,2611 hingga 122,2829 Bujur Timur serta 7,5220 sampai 7,4937 Lintang Selatan, yang terdiri dari 10 desa, 36 dusun, 85 Rw dan 306 Rt, dengan jumlah 
penduduk pada tahun 2019, sekitar 72.591 jiwa yakni, penduduk laki-laki berjumlah 37.173 jiwa dan penduduk perempuan berjumlah 35.418 jiwa (Winanto, 2019). Pujon merupakan kecamatan dengan berbagai potensi yang terdapat di dalamnya baik dari potensi pariwisata, perekonomian masyarakat, lapangan pekerjaan, sumber daya alam dan keragaman budaya yang menjadi salah satu identitas bagi Kecamatan Pujon. Dalam hal kebudayaan atau budaya Kecamatan Pujon memiliki berbagai kesenian salah satunya yakni tradisi pencak atau oleh masyarakat sekitar wilayah Pujon sering disebut dengan istilah pencak'an, yang merupakan tradisi turun temurun dari masyarakat Pujon.

Tradisi pencak merupakan salah satu bentuk budaya lokal yang hingga saat ini masih tetap dilestarikan oleh masyarakat Pujon, dimana dalam tradisi ini mengadopsi gerakangerakan dari pencak silat yang merupakan kebudayaan asli Indonesia, namun dalam tradisi pencak tradisional di daerah Pujon ini memiliki beberapa keunikan, mulai dari proses berjalannya acara yang diselingi oleh beberapa kebudayaan lain dari masyarakat Pujon dan juga penggunaan alat musik tradisional sebagai pengiringnya yang dikombinasikan dengan musik-musik khas pencak tradisional yang memiliki irama-irama tertentu. Selain itu tradisi pencak ini juga memiliki peran tertentu dalam masyarakat baik dalam hal hiburan, sosial, ekonomi ataupun yang lainnya sehingga penting untuk dikaji. Pokok pembahasan dan tujuan yang akan dimuat dalam kajian ini adalah untuk mengetahui mengenai bagaimana peranan dari tradisi atau budaya pencak ini dalam kehidupan masyarakat Pujon dan konsep penekanan apa saja yang terdapat dalam tradisi pencak tersebut (Sang, 2016).

Berdasarkan konteks kajiannya, tema mengenai tradisi pencak tradisional yang merupakan budaya lokal dari masyarakat Indonesia ini sudah beberapa kali dilakukan salah satunya yakni kajian yang dilakukan oleh Muh. Idris Saputra dari Program Studi Pendidikan Antropologi, Universitas Negeri Makassar, pada tahun 2018, dengan judul "Menca'sangge' (studi deskriptif tentang bela diri pencak silat tradisional di lingkungan Dare'e Kecamatan Tanete Riantang Timur, Kabupaten Bone" yang membahas mengenai pencak tradisional Menca'Sangge' di lingkungan Dare'e, baik dari segi religius, historis, kemanusiaan dan pendidikan yang terkandung di dalamnya serta pola pewarisan dari pencak silat tradisional tersebut, dimana hasil yang diperoleh yakni menca'sangge' atau pencak tradisional khas bone memiliki beragam nilai di dalamnya, baik dari segi makna dari setiap gerakan yang diperagakan ataupun dari beberapa aspek pendukung dalam pencak tradisional tersebut, salah satunya musik pengiring dan beberapa properti yang lainnya, sedangkan dalam proses penurunannya yakni kepada masyarakat yang masih memiliki ikatan keluarga dengan pendiri atau penggagas menca'sangge tersebut, namun kajian ini hanya terfokus pada konsep internal dari pencak tradisional menca'sangge itu sendiri sehingga bersifat kurang menyeluruh (Saputra, 2018). Kemudian juga terdapat kajian serupa yang dilakukan oleh Irvan Setiawan dari balai pelestarian sejarah dan nilai tradisi bandung pada tahun 2011 dengan judul "Eksistensi Seni Pencak Silat di Kabupaten Purwakarta (Kajian Tentang Strategi Adaptif)", dimana kajian ini membahas mengenai analisis strategi eksistensi dan adaptasi dari pencak tradisional yang ada di purwokerto dari beberapa aspek, yang meninjau dari sudut kajian olahraganya sebagai bentuk kesenian tradisional di Purwokerto, dengan hasil bahwa strategi adaptasi yang diterapkan yakni dihubungkan dengan tinjauan spiritual, media, dan seni budaya, namun dalam kajian ini lebih condong pada peran pemerintahan setempat dalam melestarikan budaya tersebut (I. Setiawan, 2011). Selain itu juga terdapat penelitian yang dilakukan oleh Mohammad Taqibul Fikri, dari IAIN Sunan Giri Bojonegoro pada tahun 2019, dengan judul "Pelatihan Kesenian Pencak Macan dalam Rangka Pelestarian dan Penanaman 
Nilai Spiritual Melalui Kesenian Tradisional", yang memiliki orientasi pembahasan mengenai bentuk-bentuk pelestarian dari pencak macan di Kabupaten Gresik, yakni melalui penanaman terhadap generasi muda sebagai sarana pelestarian budaya, namun dalam kajian ini lebih terfokus pada aspek pelestarian dari pencak macan tersebut sebagai kesenian tradisional setempat, sehingga kurang menjelaskan dari aspek pencak macan itu sendiri (Fikri, 2018). Dalam bahasan beberapa penelitian atau kajian terdahulu tersebut yang lebih menekankan pada satu ruang lingkup yang berorientasi pada beberapa sudut pandang saja, sedangkan dalam kajian dengan judul "Peran Tradisi “Pencak” Sebagai Implementasi Budaya Lokal dalam Bingkai Kehidupan Masyarakat Pujon" ini memiliki kebaharuan dari segi konsep kajiannya yakni dengan adanya analisis terhadap beberapa aspek pendukung dalam tradisi dan kesenian pencak tersebut serta hal-hal yang melatar belakanginya sehingga kajian ini dapat bersifat menyeluruh dan menghadirkan kebaruan tersendiri dalam hal analisis deskriptifnya, selain itu dalam konteks wilayah Pujon kajian dengan tema ini masih belum pernah dilakukan pengkajian sebelumnya, oleh karena itu penulis memiliki inisiatif dan tertarik untuk mengangkat tema ini sebagai objek kajian guna sebagai literatur yang nantinya dapat dimanfaatkan oleh berbagai pihak untuk menunjang kajian sejenis lainnya.

\section{Metode}

Metode yang diterapkan oleh penulis dalam penyusunan kajian ini adalah menggunakan metode kualitatif deskriptif dan kajian pustaka, dimana dalam penerapan metode kualitatif dilakukan dengan melakukan observasi dan wawancara terhadap narasumber tertentu yang dapat menambah data dari kajian ini, secara konsep diskursus penelitian kualitatif yaitu bersifat induktif, fleksibel, dinamis dan eksploratif dengan instrumen penelitian berupa buku catatan, rekaman audio, dan kemampuan seorang peneliti untuk membaca, memahami, mengolah dan menginterpretasi data, sedangkan metode studi pustaka dilakukan dengan cara mencari sumber literatur terdahulu yang berhubungan dengan topik bahasan yang diusung, baik literatur secara online maupun offline. Sumber literatur secara online diperoleh melalui artikel ataupun jurnal yang sifatnya non cetak atau melalui media internet, sedangkan sumber literatur secara offline didapat melalui observasi atau melihat secara langsung pagelaran tradisi pencak tersebut (Moleong, 2018). Peranan dan fungsi metode yang diterapkan dalam penyusunan proposal ini yaitu untuk memberikan landasan dalam mengembangkan konsep yang akan dibahas dalam penelitian ini yang bertujuan untuk memahami peranan pencak sebagai tradisi dan kesenian tradisional khas Pujon serta aspek-aspek yang terdapat didalamnya, dengan penerapan alur tertentu dalam penelitian ini yakni dengan perumusan konsep penelitian, kemudian penentuan jenis informasi atau data yang diperlukan untuk menunjang penelitian ini, serta penempatan prosedur pengumpulan dari data penelitian itu sendiri, baik melalui wawancara, observasi ataupun yang lainnya (A. A. Setiawan Johan, 2018).

Penelitian ini dilakukan di Kecamatan Pujon yang merupakan salah satu kecamatan yang terdapat di Kabupaten Malang, lebih tepatnya berada di sebelah barat yakni $+29 \mathrm{Km}$. Dengan luas wilayah sebesar 13.075,144 $\mathrm{Ha}$ atau setara dengan $34.18 \mathrm{Km}$, dan ketinggian wilayah 1.100 di atas permukaan laut, adapun batas-batas wilayah dari Kecamatan Pujon diantaranya, di sebelah utara adalah Kabupaten Mojokerto, di sebelah timur adalah Kota Wisata Batu, di sebelah selatan adalah Kabupaten Blitar di sebelah barat adalah Kecamatan Ngantang Kabupaten Malang. Untuk jumlah penduduk di Kecamatan Pujon sendiri mencapai 20.857 KK, dengan taraf peningkatan atau pertumbuhan penduduk rata-rata 0,1 persen per tahunnya (Winanto, 2019). Lokasi penelitian ini dipilih karena bertepatan peneliti juga tinggal di Kabupaten Malang sehingga memudahkan peneliti untuk melakukan penggalian data secara 
mendalam. Sasaran dalam penelitian ini yakni beberapa tokoh pemuka tradisi pencak, dengan sistem pemilihan informan yang dilakukan dengan teknik Purposive Sampling atau pemilihan sampel atau informan yang dilakukan secara sengaja dengan menerapkan kriteria tertentu seperti jangka umur, domisili wilayah dan yang lainnya, dengan tujuan untuk mendapat informasi yang dapat membantu memberikan informasi atau data secara mendalam, menyeluruh dan valid (Arieska \& Herdiani, 2018).

Penggunaan metode kualitatif dan studi pustaka dalam proses penyusunan artikel ini dilakukan dengan beberapa tahapan. Tahapan pertama yaitu persiapan dengan melakukan observasi mengenai tema yang akan dibahas yaitu tradisi dan kesenian pencak, tahap kedua adalah pengumpulan data penunjang dalam kajian yakni melalui studi pustaka secara online yaitu mengumpulkan literatur seperti artikel dan jurnal, kemudian secara offline yakni melakukan wawancara terhadap salah satu anggota dari perguruan pencak yang ada di wilayah Pujon yaitu anggota perguruan pencak Singo Manunggal Djaya yang bertempat di Desa Pujon Kidul pada tanggal 06 April 2020 pukul 17.00-18.45 WIB di kediaman narasumber yaitu mas Taufik dan juga melihat secara langsung penyelenggaraan tradisi pencak pada tanggal 16 Maret 2020, pukul 21.00-00.23 WIB yang bertempat di Desa Wiyurejo Pujon. Tahap ketiga yaitu penyusunan, yakni dengan mengakumulasi semua data dan sumber yang telah didapat sebagai landasan untuk menunjang dan mengembangkan topik atau tema bahasan yang akan dibahas dalam kajian ini.

Analisis data dalam penelitian ini dilakukan dengan menerapkan tiga konsep alur kegiatan penelitian yakni Data Reduction atau reduksi data dengan mengumpulkan data terkait pokok bahasan penelitian, Data Display atau pemaparan data untuk memperoleh pemahaman berdasarkan analisis data agar dapat mengambil tindakan tertentu, kemudian Conclusion Drawing / Verifying atau penarikan kesimpulan secara keseluruhan berdasarkan data yang telah diproses sebelumnya untuk menjawab fokus dalam penelitian ini (Creswell, 2016).

\subsection{Konsep Teori Interaksionisme Simbolik Dalam Tradisi Pencak}

Konsep dari teori interaksionisme simbolik pertama kali diperkenalkan oleh Herbert Blumer pada tahun 1939, dalam ruang lingkup sosiologi konsep dalam teori ini telah diperkenalkan terlebih dahulu oleh George Herbert Mead yang kemudian dikembangkan oleh Herbert Blumer (Agus Maladi Irianto, 2015). Esensi yang terdapat dalam teori interaksionisme simbolik berangkat dari suatu aktivitas yang merupakan ciri dari manusia seperti komunikasi atau pertukaran simbol yang memiliki makna (Oktaviani, 2014). Teori interaksionisme simbolik merupakan bentuk pemahaman mengenai hubungan yang terjadi antara individu dengan individu, individu dengan kelompok dan kelompok dengan kelompok dalam masyarakat (Siregar, 2011). Secara umum teori interaksionisme simbolik dapat di dasarkan pada interaksi sosial dalam masyarakat dimana manusia menerima dan memberi respon terhadap manusia yang lainnya dengan sifat interaksi fleksibel dan bervariasi, selain itu teori interaksionisme simbolik juga bertujuan untuk memberikan makna, menggambarkan, dan mempresentasikan suatu interaksi yang terdapat dalam lingkup masyarakat (Ahmadi, 2008).

Teori interaksionisme simbolik menurut Blumer memiliki dasar pemikiran yakni 3 premis. Bila dikaitkan dengan tradisi ataupun kesenian pencak tradisional dari Pujon, dapat di implikasikan sebagai berikut (Ahmadi, 2008): 1) Tindakan manusia berdasarkan pada suatu 
makna yang ada pada hal-hal tertentu. Yakni tindakan yang dilakukan seperti pagelaran seni pencak secara rutin maupun yang lainnya memiliki pemaknaan tertentu dalam masyarakat, baik pemaknaan dari segi religiusitas melalui simbol-simbol dan ritual tertentu dalam pelaksanaan pencak tersebut ataupun hal-hal yang lainnya. 2) Makna berasal dari suatu interaksi sosial yang terjadi dalam masyarakat. Interaksi yang biasa terjalin dalam hal pelestarian kearifan lokal pencak ini yakni adanya beberapa orang atau kelompok yang mengadakan tasyakuran ataupun acara tertentu seperti pernikahan, khitanan dan yang lainnya, dengan mengadakan kesenian tersebut, hal ini dapat dimaknai sebagai sebuah interaksi yang nantinya dapat di implementasikan untuk melestarikan kesenian pencak itu sendiri. 3) Makna dalam suatu interaksi sosial dapat disempurnakan melalui proses berlangsungnya interaksi tersebut. Dengan terselenggaranya atau terdapatnya beberapa orang yang memanfaatkan kesenian pencak untuk kebutuhan tertentu tersebut dapat memunculkan adanya aspek-aspek lain yang dapat menyempurnakan proses pelaksanaan tradisi pencak itu sendiri, yakni adanya konsep hiburan, sosial, ekonomi serta pelestarian budaya yang dapat tercermin dengan adanya pelaksanaan kesenian pencak tersebut, sehingga dengan adanya keterkaitan antar komponen-komponen tersebut dapat menjaga kelestarian kearifan lokal pencak itu sendiri.

Masyarakat dalam pandangan teori interaksionisme simbolik merupakan suatu kerangka dimana di dalamnya terdapat tindakan sosial yang berlangsung sehingga menjadi rancangan dasar timbulnya interaksi sosial (Luthfie et al., 2017). Adapun prinsip-prinsip dasar yang terdapat dalam teori interaksionisme simbolik yang dapat diimplementasikan dalam tradisi atau kesenian pencak silat tradisional di Pujon, yakni: 1) Konsep diri (Self), konsep bahwa manusia tidak hanya bergerak atau merespon dari adanya suatu stimulus namun juga berdasarkan pikiran yang berasal dari dirinya sendiri, seperti halnya upaya pelestarian kesenian pencak yang dilakukan oleh msyarakat wilayah Pujon melalui adanya pagelaran tradisi pencak dalam beberapa acara masyarakat yang berdasar pada inisitaif masyarakat itu sendiri untuk menampilkan tradisi pencak dalam setiap acara tersebut. 2) Konsep perbuatan (Action), yakni adanya sebuah interaksi yang terbangun atas keadaan atau situasi tertentu, yaitu adanya hubungan interaksi sosial dalam berjalannya tradisi pencak tersebut, baik interaksi antara masyarakat dengan masyarakat lainnya ataupun masyarakat dengan kelompok atau komunitas perguruan pencak itu sendiri. 3) Konsep objek (Object), merupakan cara pandang dalam hal memposisikan sesuatu, dimana dalam setiap pelaksanaan tradisi pencak tersebut setiap masyarakat memiliki konsepsi cara pandang tersendiri terhadap kesenian pencak tersebut, baik memandang tradisi pencak dari segi hiburan, pelestarian budaya, ataupun dari segi spiritualitas dalam tradisi pencak itu sendiri. 4) Konsep interaksi sosial (Social Interaction), yakni adanya konsep memahami terhadap aksi yang dilakukan oleh orang lain. Di sisi lain dalam tradisi atau kesenian pencak juga terdapat konsep interkasi sosial seperti pembeli dan penjual dalam pelaksanaan pagelaran pencak ataupun yang lainya. 5) Konsep tindakan bersama (Joint Action), yakni merupakan bentuk kesatuan segala aspek interaksi yang dapat melahirkan aksi kolektif tertentu. Dalam pencak konsep ini dapat di representasikan dengan kontribusi dari segala pihak dalam setiap pengadaan pagelaran pencak itu sendiri, baik dari masyarakat, pemerintah desa, komunitas pencak dan pelaku yang lainnya, dimana dengan adanya kontribusi dari masing-masing pihak tersebut dapat membuat tradisi pencak tersebut menjadi lestari dan tetap terjaga melalui adanya pengelaran yang dilakukan secara rutin. 


\section{Hasil dan Pembahasan}

\subsection{Konsep dan History Tradisi Pencak di Kecamatan Pujon}

Pencak atau biasa disebut dengan istilah pencak'an oleh masyarakat Pujon adalah salah satu bentuk tradisi atau budaya lokal yang berada di daerah Pujon. Sejarah dari adanya tradisi pencak yang berada di daerah Pujon ini berasal dari keinginan masyarakat untuk berjuang dalam mempertahankan kawasan daerahnya pada masa kolonial belanda, pada masa itu masyarakat Pujon memiliki inisiatif untuk belajar bela diri tradisional kepada seseorang yang memiliki keahlian dalam seni bela diri pada masa itu dengan tujuan untuk mempertahankan wilayahnya dari jajahan orang belanda. Setelah Indonesia merdeka, kemampuan bela diri yang dimiliki oleh beberapa masyarakat Pujon pada saat itu mulai diturunkan dari generasi ke generasi dan mulai berkembang sebagai suatu tradisi atau kebudayaan lokal dari masyarakat Pujon. Seiring dengan berkembangnya waktu dan perubahan yang terjadi secara signifikan, tradisi ini mulai digemari oleh masyarakat Pujon, hal ini terbukti dengan berdirinya beberapa perguruan pencak silat di berbagai desa di wilayah Pujon. Sedangkan dari sumber lain mengatakan bahwa tradisi dan kesenian pencak di daerah Pujon berasal dari kerajaan Singasari, dimana sering diadakan pagelaran adu kesaktian dari para prajurit kerajaan Singasari sebagai salah satu cara untuk melihat perkembangan kemampuan prajurit kerajaan serta juga sebagai hiburan atau tontonan untuk mengisi waktu luang di dalam kerajaan, dari sinilah tradisi atau kesenian pencak muncul dan mulai dimodifikasi sesuai dengan berkembangnya zaman. Seiring dengan perkembangan zaman pencak tidak hanya ditujukan sebagai sarana perlindungan diri namun juga sebagai penerapan nilai-nilai estetika yang terdapat di dalamnya sehingga dapat menjadi sebuah tradisi ataupun budaya lokal dalam bentuk kesenian daerah. Beberapa perguruan pencak yang terdapat di daerah Pujon antara lain yaitu: 1) Perguruan Pencak Putra Panji. Perguruan ini telah berdiri sejak tahun 1963 dan bertempat di desa Madiredo dengan jumlah anggota sebanyak 70 orang dan diasuh oleh Bapak Samiudin yang telah berusia 40 tahun. 2) Perguruan Pencak Singa Manunggal Djaya. Perguruan pencak manunggal jaya telah berdiri sejak tahun 1998 dan saat ini diasuh oleh Bapak Wiranto yang telah berumur 43 tahun, dan bertempat di dusun Kerajan Desa Pujonkidul dengan jumlah anggota sekitar 102 orang. 3) Perguruan Pencak Rukun Abadi. Perguruan ini bertempat di dusun Gesingan yang telah berdiri sejak 67 tahun yang lalu dan di asuh oleh Bapak Mudjiono dengan jumlah anggota sekitar 30 orang.

Secara umum konsep dari tradisi pencak di daerah Pujon merupakan bentuk adaptasi dari pencak silat yakni dari aspek gerakan-gerakan yang dilakukan secara berulang-ulang dan beberapa ciri khas yang ditonjolkan dalam pencak silat seperti senjata ataupun yang lainnya, namun yang membedakan tradisi pencak ini dengan pencak silat secara umum adalah terletak pada penggunaan alat musik tradisional dan juga iringan lagu-lagu tradisional yang memberikan kesan tersendiri dalam tradisi ini (P \& esari, 2016). Selain itu dalam proses pencak ini sendiri juga terdapat beberapa kesenian lain yang juga ditampilkan atau sudah menjadi satu kesatuan setiap tradisi ini dilestarikan, yakni penampilan dari kesenian jaran kepang, barongan dan bantengan yang juga merupakan beberapa kesenian yang terdapat di daerah Pujon. Penyelenggaraan tradisi pencak ini pada umum adalah pada bulan dan hari-hari tertentu menurut kepercayaan penanggalan orang jawa, namun seiring dengan kemajuan zaman dan modernisasi tradisi ini mulai dipertunjukan dalam kegiatan atau acara-acara yang diselenggarakan oleh warga seperti peringatan bersih desa, hajatan pernikahan, sunatan/khitanan, dan kegiatan budaya lainnya. 


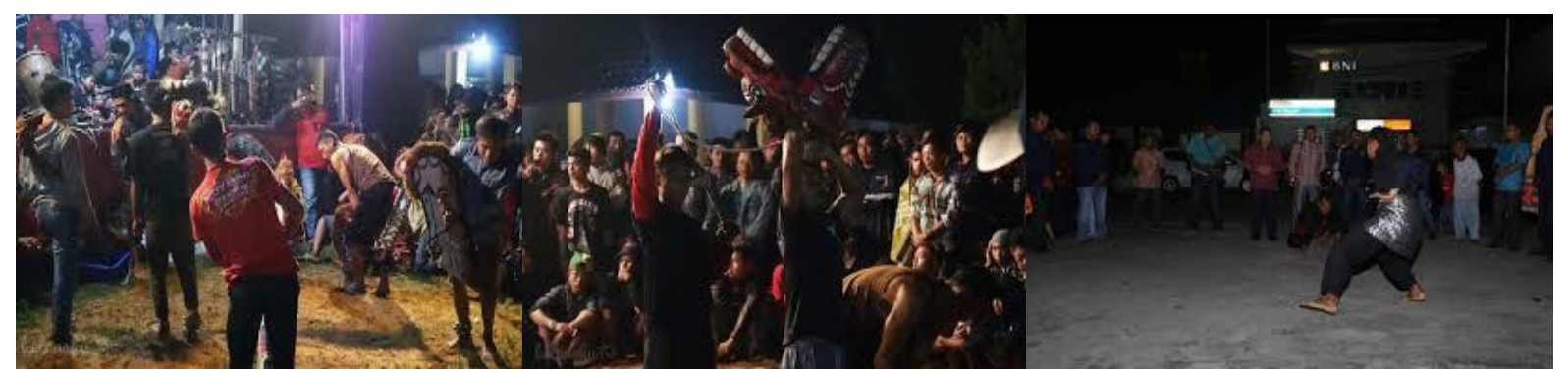

Gambar 1. Prosesi tradisi Pencak, mulai dari penampilan Bantengan, Jaran Kepang, Barongan dan Pencak

Sumber: Budayajawa.id

Prosesi berjalannya tradisi atau kesenian pencak ini biasa diselenggarakan pada malam hari sekitar jam 20.00 WIB ke atas sampai acara selesai, yang biasa bertempat di tempattempat tertentu seperti pertigaan dan perempatan jalan serta lokasi terbuka seperti lapangan dan yang lainnya, dimana prosesi tradisi pencak ini dimulai dengan pembukaan yang dilakukan oleh pemimpin atau orang yang dituakan dalam kesenian pencak itu sendiri, kemudian dilanjutkan dengan penampilan dari kesenian bantengan yang merupakan kesenian dengan menggunakan media kayu berbentuk kepala banteng sebagai representasi banteng, dimana dalam kesenian yang pertama ini pemainnya mengalami kesurupan atau kemasukan danyang (roh) sehingga hilang kesadaran normalnya. Setelah itu dilanjutkan dengan kesenian jaran kepang atau kuda lumping dan barongan yang secara teknis memiliki kesamaan dengan kesenian bantengan namun memiliki media yang berbeda yakni jaran kepang atau kuda lumping menggunakan media kuda yang terbuat dari anyaman bambu dan barongan menggunakan media seperti kepala naga lengkap dengan ukiran yang menambah aksen tradisional dengan ciri khas tersendiri dari kesenian barongan tersebut, kemudian prosesi terakhir atau puncak adalah tradisi atau kesenian pencak. Dalam prosesi berlangsungnya tradisi ini sering disebut dengan istilah pencak'an yakni kata yang ditujukan kepada seseorang yang sedang melakukan atau menampilkan gerakan-gerakan pencak yang diadopsi dan dimodifikasi dari gerakan pencak silat secara umum, dimana dalam penampilan tradisi atau kesenian ini terdapat beberapa orang yang saling bergantian dalam menunjukan beberapa gerakan-gerakan silat tradisional yang disesuaikan dengan irama atau ketukan dari alat dan musik tradisional, setelah itu baru dilanjutkan dengan penampilan pencak lain yang dilakukan oleh dua orang yang saling menunjukan kemampuannya menguasai beberapa gerakan pencak baik menggunakan senjata ataupun dengan tangan kosong, tak jarang juga dalam prosesi pencak'an yang dilakukan oleh seseorang dalam keadaan kerasukan atau kemasukan danyang roh leluhur yang membuat seseorang tersebut kehilangan kesadaran dan melakukan gerakangerakan silat tertentu yang dilakukannya tanpa kesadaran dari dirinya atau dengan kata lain seseorang tersebut dijalankan oleh danyang atau roh leluhur yang merasukinya, selain itu dalam pencak ini juga menampilkan atraksi-atraksi dari para peserta pencak, yakni tradisi yang berhubungan dengan kekuatan fisik dari seseorang dan juga berkaitan dengan tenaga dalam seseorang seperti menghancurkan batu bata, tidak mempan ditusuk, dibacok atau ditebas dengan senjata tajam dan yang lainnya. Untuk pakaian atau kostum yang digunakan dalam prosesi tradisi pencak ini di dominasi oleh warna hitam dengan sabuk juga berwarna hitam dan ciri khas udeng yang diikatkan di kepala atau anggota tubuh yang lainnya. Dalam setiap penampilan kesenian yang ditampilkan dalam tradisi ini semuanya diiringi dengan alat musik dan musik yang bernuansa klasik atau tradisional (Shihab \& Musiasa, 2017). Adapun 
beberapa bentuk peralatan alat musik dan musik yang dimainkan dalam tradisi ini adalah alat musik pencak kategori tradisional, yaitu kendang, terompet, bonang, kenong, dan gender. Sedangkan alat musik pencak kategori modern meliputi gitar, kibor, dan alat elektronik lainnya (Mardotillah \& Zein, 2017).

Dalam tradisi pencak kendang yang digunakan terbagi menjadi dua kategori yaitu kendang alusan atau serampat dan kendang jidor. Dalam prosesi pencak kendang memegang fungsi penting dalam menentukan gerakan dari pemain pencak, dimana ketukan yang dihasilkan oleh kendang tersebut berkaitan dengan gerakan-gerakan yang digunakan oleh pemencak tadi.

Terompet yang digunakan dalam kesenian atau tradisi ini adalah trompet yang dapat menghasilkan suara nyaring, yang terbuat dari kayu dan memiliki ciri khas penempatan bentuk untuk tempat meniup terompet yang unik.

Bonang merupakan alat musik yang memiliki fungsi untuk memberikan kesan melodi tertentu dalam alunan musik, bonang terbuat dari perunggu dan biasanya berjumlah 14 buah yang disusun sejajar dan berderet.

Kenong adalah salah satu alat musik pelengkap dalam tradisi pencak karena fungsi dari kenong sendiri adalah untuk memberikan aksen penegasan pada melodi yang dihasilkan dari alat musik yang lainnya.

Gender merupakan salah satu alat musik gamelan yang terbuat dari kuningan dengan bentuk bilah-bilah yang disusun secara sejajar sesuai ukuran tertentu, dengan jumlah dari 10 sampai 14 bilah dalam satu deret.

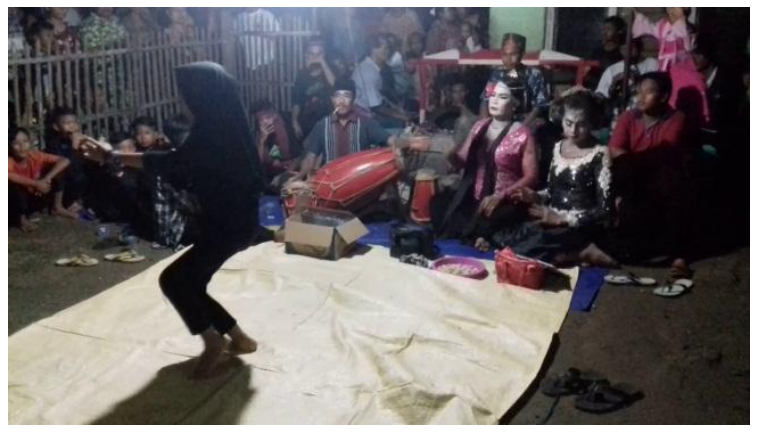

\section{Gambar 2. Sinden yang sedang mengiringi pencak dengan lagu-lagu tradisional Sumber: Budayajawa.id}

Lagu yang biasa digunakan dalam prosesi kesenian ini adalah lagu-lagu klasik yang bersifat tradisional seperti gending jati ngarang dan sunda yang biasa dinyanyikan oleh sinden dalam pencak, dimana penempatan dan pemilihan lagu dalam prosesi ini memberikan aspek penting dalam hal estetika dari gerakan dan sinkronisasi gerakan yang ditampilkan dengan musik itu sendiri. Dengan kata lain musik atau lagu dalam prosesi ini memiliki hubungan yang saling berkaitan dan saling mempengaruhi (Fauzi, 2016). Seiring dengan perkembangan zaman musik atau lagu yang dimainkan dalam tradisi ini mulai dipengaruhi oleh musik-musik yang bersifat modern seperti lagu dangdut yang diberikan aksen klasik menggunakan alat-alat musik tradisional sehingga musik-musik dengan kategori klasik atau tradisional mulai jarang ditemukan dalam tradisi ini, namun untuk alat musik dan musik yang modern lebih condong 
digunakan untuk mengiringi kesenian yang lain dalam tradisi ini seperti bantengan dan barongan.

\subsection{Peranan Tradisi Pencak Bagi Masyarakat Kecamatan Pujon}

Pencak sebagai salah satu tradisi dan kesenian atau budaya lokal tidak terlepas dari konsep masyarakat dimana dalam hal ini bentuk peranan yang diperankan oleh kesenian pencak dalam masyarakat Pujon terbagi menjadi beberapa kategori atau aspek yakni sebagai berikut:

\subsubsection{Sebagai Hiburan atau Tontonan}

Sebagai sebuah tradisi, kesenian pencak ini tidak terlepas dari antusiasme masyarakat yang ingin menyaksikan kesenian ini selain untuk melestarikan, tradisi ini juga sering dimanfaatkan oleh masyarakat sebagai sarana hiburan untuk menghilangkan kejenuhan setelah pulang kerja, dimana tradisi ini dilakukan pada waktu-waktu longgar masyarakat yakni sekitar jam 20.00 WIB, sehingga masyarakat banyak yang merasa senang dan terhibur dengan adanya tradisi ini.

\subsubsection{Sebagai Sarana Sosial Masyarakat}

Dalam peranan ini tradisi pencak memiliki fungsi untuk mengumpulkan masyarakat, dimana dengan berkumpulnya masyarakat tersebut terjalin sebuah interaksi antar anggota masyarakat sehingga proses sosial juga dapat berlangsung melalui media pelestarian tradisi ini, baik dalam bentuk hubungan interaksi antara penjual dan pembeli dalam tradisi pencak tersebut ataupun dalam bentuk bertegur sapa dengan masyarakat lainnya.

\subsubsection{Sebagai Upaya Pengenalan dan Pelestarian Budaya dalam Masyarakat}

Sebagai sebuah bentuk tradisi ataupun budaya lokal penting adanya pengenalan kepada masyarakat terutama anak-anak muda agar nantinya bisa tetap melestarikan tradisi dan kesenian tersebut, dengan kata lain peranan ini ditujukan untuk menjaga keberlangsungan atau kelestarian dari tradisi pencak itu sendiri (Fikri, 2018).

\subsubsection{Sebagai Lapangan Ekonomi bagi Sebagian Masyarakat}

Adanya sifat sebagai tontonan dan hiburan dalam masyarakat menjadikan tradisi ini tidak terlepas dari masyarakat yang memanfaatkan kondisi ini sebagai ladang untuk mencari uang yakni dengan berdagang di sekitar tempat di selenggarakannya tradisi tersebut, seperti berdagang makanan ringan ataupun yang lainnya. Sehingga dengan diadakanya tradisi dan kesenian pencak ini juga memberikan dampak perekonomian bagi masyarakat sekitar Pujon (Utomo \& Satriawan, 2017).

\subsection{Dampak Negatif Tradisi Pencak di Kecamatan Pujon}

Secara umum tradisi pencak yang terdapat di daerah Pujon tidak terlepas dari peran masyarakat sebagai pelestari dari tradisi ini sendiri oleh karena itu masyarakat daerah Pujon sering mengadakan beberapa pagelaran tradisi pencak itu sendiri. Namun selain berbagai dampak positif yang ada dalam tradisi pencak ini, juga terdapat sisi negatif dalam tradisi ini 
yakni beberapa anak muda yang sering memanfaatkan penyelenggaraan tradisi ini sebagai ajang untuk mabuk-mabukan serta berkelahi atau tawuran antar masyarakat, sehingga banyak penyelenggaraan tradisi ini mulai di bantu oleh aparat desa seperti linmas dan yang lainnya untuk membantu proses pengamanan dari berjalanya tradisi pencak tersebut.

\section{Simpulan}

Pencak sebagai salah satu tradisi, kesenian dan budaya lokal yang terdapat di wilayah Pujon merupakan representasi dari masyarakat Pujon itu sendiri seperti usaha dalam menjaga tradisi, memiliki kegigihan dalam berusaha dan menghargai tradisi. Dalam konsep tradisi dan kesenian pencak, peran masyarakat didalamnya sangatlah penting, dimana masyarakat memiliki peran untuk selalu melestarikan tradisi itu sendiri. Bila ditinjau dari sudut peranannya tradisi pencaik di Kecamatan Pujon memiliki beberapa peranan seperti, sebagai sarana hiburan melalui adanya tontonan kesenian pencak itu sendiri dan sebagai sarana pelestarian warisan leluhur yang harus terus dijaga kelestariannya. Sedangkan dari sisi aspekaspek yang terdapat dalam pelaksanaan atau penyelenggaraan pencak di Kecamatan Pujon terdapat beberapa hal, yakni aspek sosial dalam masyarakat melalui interaksi yang terjalin dengan adanya penyelenggaraan tradisi dan kesenian pencak, aspek ekonomi yang ditunjukan dengan adanya beberapa masyarakat yang memanfaatkan penyelenggaraan kesenian pencak itu sendiri sebagai sarana untuk mencari penghasilan dengan berjualan di sekitar tempat penyelenggaraan pencak tersebut, selain itu secara keseluruhan konsepsi yang terdapat dalam tradisi ini memiliki berbagai cakupan mulai dari golongan muda hingga golongan tua, hal ini juga menunjukan bahwa kesenian dan tradisi ini memiliki sifat general untuk semua lapisan masyarakat dan tidak membeda-bedakan masyarakat berdasarkan hal-hal tertentu atau dengan kata lain tradisi dan budaya yang ada di wilayah Pujon ini merupakan tradisi dan kesenian milik semua masyarakat.

\section{Daftar Rujukan}

Irianto, A. M. (2015). Interaksionisme simbolik. Pendekatan Antropologis Merespons Fenomena Keseharian. Gigih Pustaka Mandiri.

Ahmadi, D. (2008). Interaksi Simbolik: Suatu Pengantar. Mediator: Jurnal Komunikasi, 9(2), 301-316.

Arieska, P. K., \& Herdiani, N. (2018). Pemilihan Teknik Sampling Berdasarkan Perhitungan Efisiensi Relatif. Jurnal Statistika Universitas Muhammadiyah Semarang, 6(2).

Creswell, J. W. (2016). Research design: pendekatan metode kualitatif, kuantitatif, dan campuran. Yogyakarta: Pustaka Pelajar, 5.

Fauzi, M. R. (2016). Tarian Dalam Pencak Silat Tradisional di Desa Sumbergondo Kecamatan Bumiaji Kota Batu Sebuah Kajian Folklor (Doctoral dissertation, Universitas Muhammadiyah Malang).

Fikri, M. T. (2018). Pelatihan Kesenian Pencak Macan dalam Rangka Pelestarian dan Penanaman Nilai Spiritual melalui Kesenian Tradisional. Al Ulya: Jurnal Pendidikan Islam, 3(1), 97-109.

Luthfie, M., Hubeis, A. V. S., Saleh, A., \& Ginting, B. (2017). Interaksi Simbolik Organisasi Masyarakat Dalam Pembangunan Desa. INFORMASI Kajian Ilmu Komunikasi, 47.

Mardotillah, M., \& Zein, D. M. (2017). Silat: Identitas budaya, pendidikan, seni bela diri, pemeliharaan kesehatan. Jurnal Antropologi: Isu-Isu Sosial Budaya, 18(2), 121-133.

Moleong, L. J. (2018). Metodologi Penelitian Kualitatif (Revisi : Cetakan Ke 38). PT Remaja Rosdakarya.

Oktaviani, C. (2014). Teori Sosial Interaksionisme Simbolik. https://www.academia.edu/29794413/Teori_Sosial_Interaksionisme_Simbolik_docx

P, W. D. \& esari. (2016). Wisata Desa Pandesari: Kesenian Pencak Silat dan Bantengan Krajan. Wisata Desa Pandesari. http://wisata-desapandesari.blogspot.com/p/blog-page_51.html 
Jurnal Integrasi dan Harmoni Inovatif Ilmu-Ilmu Sosial, 1(4), 2021, 517-527

Sang, K. (2016). Kang Pit Sahabat Kita dari Kesenian Pencak Silat 'Singa Manunggal Djaya' Pujon. http://www.sangkawi.com/2016/03/kang-pit-sahabat-kita-dari-kesenian.html.

Saputra, M. I. (2018). Menca'sangge'(Studi Deskriptif tentang Bela Diri Pencak Silat Tradisional di Lingkungan Dare'e Kecamatan Tanete Riattang Timur Kabupaten Bone (Doctoral dissertation, Universitas Negeri Makassar).

Setiawan, A. A., Johan. (2018). Metodologi Penelitian Kualitatif. CV Jejak (Jejak Publisher). https://books.google.com/books?hl=en\&lr=\&id=59V8DwAAQBAJ\&oi=fnd\&pg=PP1\&dq=penelitian+k ualitatif\&ots=5HbwnydsJt\&sig=8nCWYGI1dzxZZkugyc8ZGGcn9F8

Setiawan, I. (2011). Eksistensi Seni Pencak Silat di Kabupaten Purwakarta (Kajian Tentang Strategi Adaptasi). Patanjala, 3(3), 424-441.

Shihab, M., \& Musiasa, I. N. (2017). Strategi Public Relations dan Pencak Silat Tradisional. Jisip: Jurnal Ilmu Sosial dan Ilmu Politik, 6(1).

Siregar, N. S. S. (2012). Kajian Tentang Interaksionisme Simbolik. Perspektif, 1(2), 100-110.

Tobing, I. (2018). Makalah Keragaman Budaya Indonesia 3.

Utomo, S. J., \& Satriawan, B. (2017). Strategi Pengembangan Desa Wisata di Kecamatan Karangploso Kabupaten Malang. Jurnal Neo-Bis, 11(2), 142-153.

BPS. (2019). Kecamatan Pujon Dalam Angka 2019 (Vol. 65). BPS Kabupaten Malang. https://malangkab.bps.go.id/publication/2019/09/26/f029219eb10ba391584d5c0d/kecamatanpujon-dalam-angka-2019.html 